\title{
Pure Love Redefined
}

\author{
Jyotirmoy Sarkar ${ }^{1 *}$
}

\section{ABSTRACT}

Love ---the most sweet and lovely word to all of us. There are different forms of love. But the most well known pure love is the Mom's love for their children, its most selfless love in the world, probably in the whole universe----but is it really true for every Mom?

Let's see what the logic from the practical incidents leads us, let's start with a question---how many girls and boys are there who have dedicated their whole life for their lover? The answer is --such dedication is very hard to see, after falling in love we make lots of promises to our lovers but when the time comes to keep those promises we make lots of excuses, both the boys and the girls start to sow lots of excuses, girls never find any problem to choose a secured life ignoring love, girls have lots of excuses to be got married as soon as possible, such as, security in life, complication during delivery in old age etc. But if a girl purely loves a boy then should these thoughts come in her mind? If comes then is it a pure love?

Moms love is a worldwide known pure love but how much is it an example of selfless love? Specially how much is it applicable for those girls who always wanted to secure their life without dedicating small time period for the pure love they have got, those who can't dedicate ,who can't make sacrifices for their love can never love their children purely, their love for their children is the love for their "own Part" which they brought up in their womb for nine months supplying biological and chemical ingredients ,they have supplied it from their own body that's why they have so much love for their own part----so for these types of girls, their love as mom can never be a selfless love.

Keywords: Love, Pure Love, Humanity, Sacrifice, Dedication, Mom, Selfish Love.

Love---the most lovely and sweet emotion of all of us, it becomes very close to our heart after a certain age, that's the reason we fall in love, we love and we make promises, a lots of promises to our lovers. There days during love are the most colorful days till then; we dream lots of dreams.

At the end our love meets two endings ---one is break-up and another meets whole life relationship, that's marriage. After breakup, in most of the cases we start to blame each other, we

\footnotetext{
${ }^{1}$ Science Graduate.

*Corresponding Author

(C) 2015 I J Sarkar; licensee IJIP. This is an Open Access Research distributed under the terms of the Creative Commons Attribution License (http://creativecommons.org/licenses/by/2.0), which permits unrestricted use, distribution, and reproduction in any Medium, provided the original work is properly cited.
} 


\section{Pure Love Redefined}

tell our lovers as the main culprit for breakup, even sometime we use slang languages for him/her, but the truth is, it takes two to make a quarrel, so both the lovers had mistakes and faults for breakup, someone had much more than other one, but nobody cares about it, observing the behaviors of lovers after break up it will appear that not only their love but also their humanity has vanished. After breakup our so much love vanishes suddenly and vanishes such an extent that it never existed.

We should be careful about it, when we are making promises to someone the most close to our heart, we must have to try to fulfill those promises, this is humanity, and only a true person can love truly, so before being a true lover a person must be a true person. Now let's see love from another point of view ----the love of a mother for her children is un-describable, if the son dies suddenly then still the mother loves that children, no one can take that place of that son, this is what a pure love is, this amount of love we all should have for our lovers ---but do we really have so much love in our heart? Very few persons are there who can love so much and they are the pure lovers and above all a pure human being

The journey of life is not at all smooth; everyone has to face obstacles and problems in life, if we don’t leave our lives then why we will leave our love?

\section{PURE LOVE:}

Pure love is full of dedication, sacrifice and its always unconditional, when we love someone purely, then we must not keep any conditions there, just like the love of a mother, every mother love their children unconditionally, mother's love for her child never decreases, mothers are always there to stand beside their children irrespective of behaviors a mother gets from her child. If we love someone purely we also should not be angry on our lovers after breakup, if our love is really pure then we must have the same feeling of love even after breakup. Actually ego (negative sense) is the main reason we became angry upon our lovers after break up and then we start to perform unethical activities to torture our Ex-lovers and in later life we describe our love story to others showing how much great lover we were and also never make mistake to blame our partner for our breakup. So what will we teach to our next generation? If we perform unethical and immoral works then how can we show right path to our next generation?

Sacrifice is the biggest base of love, not only during love but also after breakup, obviously if you loved truly. But the fact is most of the people are busy to find another partner after few days or months after breakup, after breakup a competitive mentality arises in the mind of both the girl and the boy, they become busy to show one another that how much happy they are without him/her. A pure love should not meet breakup, but still there is something named "fate", if for this reason a pure love meets an end, then at least after breakup they should not perform any mean works to torture each other, rather they should keep the respect of their love they had. 
Moms make lots of sacrifices for their children; fathers also make such sacrifices, after being a mom or a dad every person does such sacrifices----then why not as a lover ? Only because that there is no 'feelings of self' related to our lovers!!!!

Now the question may arise that how can we decide that our love is pure? obviously it depends upon our intentions when we start to love someone, if we start to love someone with the intention that one day we will leave our lovers, if we start to love someone with a mentality that it's just an entertainment, if we start to love someone with the intention that we will get lots of profit from our lovers in future then surely these are not pure or true love, it's actually a game we play with the emotions of someone. This game is the most dangerous, unethical and immoral game, if someone plays such a game with us then we will surely never forgive that person but when we play such a game then it’s alright!!!

\section{HUMANITY:}

There are three consequences related to our faults and mistakes----one, some mistakes and faults can never be made right----one day we have to suffer for those.

Two, some mistakes and faults can be made right---- but ego prevents us to do so.

Three--- for some mistakes and faults we have the chance to beg pardon but we can never get back the things----we have to suffer for these.

But the biggest question is ----how many of us have the so much conscience or purity to beg pardon for our mistakes? How many of us have has the true strength to admit our mistakes? actually we never look at ourselves in egoless view, we are always busy to analyze the faults and mistakes of others, practically we make comparison of our faults with others and at the end we obviously declare ourselves much better than others because every time we announce ourselves as the less faulty than others. To be a pure human being and to be a pure lover, we just have to forget what others have done, if we really have an open mind, broad point of view and a good heart then we should be pardon for our faults and mistakes, if we can do it then it will surely give us mental peace and satisfaction in later life and will surely make our love life much better and will progress towards best. If we can beg pardon for our mistakes then at the old age we will be satisfied by thinking that----there is at least one work that we have done properly. Satisfaction and mental peace, these are the two things that we want at the end of our life's journey.

\section{SELFISH LOVE:}

Those boys and girls who did not have dedication, sacrifice and purity for their love, who have ditched or left their girlfriend/boyfriend, in later life they get married with some another girl/boy, and naturally they become father or mother and we start to think that their love for their children is pure and selfless, but the question is ---how it can be possible? 


\section{Pure Love Redefined}

Actually those types of parents love their children only because their children are their own part. As I have mentioned earlier that the love of a mother is always cited as an example of a selfless love, but how can this theory is applicable for those girls who have ditched their lover? But still we can see that these types of girls have a deep love for their children, so how is it possible? it's possible because these types of mothers love their children only for the reason that these children are their own part, which they have brought up in their womb for nine months supplying biological and chemical ingredients, they have supplied it from their own body and naturally a feeling of self is related there, that's why they have so much love for their--- own part, so for these types of girls, their love as mom can never be a selfless love.

These types of girls do not know what selfless love is, they only love themselves and anything related to their own part. One of the reasons of love of such mothers for their children is for the expectations; they expect that one day their children will look after them, especially when they will be disabled.

Here the question may arise that ---these types of boys/girls love their parents, and then is not it pure? --- The fact is, there is also a feeling of 'self' is related there, just like the sense is related to their own children. If we can love purely, if we can dedicate our life for someone who is not related to our own part, where there are no feelings of self from the beginning ----then that love can be called a pure love.

Now the question is who will admit that he/she has ditched his/her lover? Actually no one or very few persons, because we are always busy to show that how much good we are, we are busy to show how much correct we are, that's why I have mentioned earlier that----every time we announce ourselves as the less faulty than others, and this happens due to our ego(in negative sense).

But the fact is one day will come, will come for sure, when we will realize our mistakes and faults and may be at that time we will not get chance to recover them, even it may happen that we will not get chance to beg pardon and we have to spend rest of our life regretting for the mistakes we have done-----that will pinch our conscience giving only pain and pain and pain.

\section{PSYCHOLOGICAL ASSESSMENT---THE SOLUTION:}

Ditch---a very common word related to breakup, if we can ditch one person then we can ditch more persons also, because ditching is in our nature. We should be careful about this; psychological assessment is very much effective to overcome such negative natures. Sometime our anger leads us towards unethical works, sometime out of anger we make big mistakes, we should not give our anger any chance to act in every steps of lives, with everyone related to us and also with our lover. If we were in a true love with someone and may be for some reasons we have to get married with another person, then we must tell our life partner all those incidents related to our past love and then if our partners love us as much as they used to do before 


\section{Pure Love Redefined}

knowing the truth of our life then----we are a lucky guy to have a such a life partner. And if we hide our truths from our life partners then surely we are an imposter and one day we will surely feel that our whole life relationship was based on lie and with that base whatever we have got was also not true and so not pure. So we should not ditch ourselves, should not ditch others.

It's true that it's not right to compare the love of a Mom for their children with any other types of loves but if we make it an ideal, if we try to dedicate our lives and try to make sacrifices like a mother then our love will surely meet an happy ending not only by getting married with our lover but also after marriage----a happy married life.

If being a Mom or a Dad we can love our children selflessly that means making a selfless love is in our nature then why can't we love our lover selflessly?

So the conclusion is----if selfless love is in our nature then we can apply it not only for our children but also for our lovers and if we are selfish then we will surely ditch our lovers and still we will demand that our love for our children is selfless.

\section{ACKNOWLEDGMENT:}

1. My parents.

2. Special thanks to all those, who loved and betrayed.

3. All those Lovers, who Loved, Fought for it and won.

4. My cousin S. Sinha.

\section{REFERENCES:}

Available from; http://www.berkeley.edu/news/media/releases/2001/02/07_love.html

John Dewey, How we think, D.C. Heath \& Co.; 1910

Kathleen Scalise, after the break-up, your "first love" never really leaves you, according to student research at UC Berkeley

Rev. Master, Character is pure Love, A talk on $23^{\text {rd }}$ November, 2008 at Manapakkam, India

Sigmund Freud, On Metapsychology New Delhi, Shrijee’s Book International. First Impression: 2003

Thomas David Kehoe, Relationships. Wiki books 2011. 